\title{
Taarapita - saarlaste suur jumal
}

\section{Urmas Sutrop}

Taarapita on meile tuttav Henriku Liivimaa kroonikast. Selle järgi lennanud ta kunagi ühelt mäelt, kus ta sündis (arvatakse et see oli Ebavere mägi või Vaivara Sinimägedes), Saaremaale. Saarlased rõõmustasid karjudes oma Taarapita üle. Lõpuks, kui kogu maa ristitud, riialased visanud ta aga maalt välja ja uputanud merre. On oletatud, et Taarapita lennutee vastab Kaali meteoriidi langemise teele (Lõugas 1996; vt ka Viires 1990: 1420). Meteoriit oli Eesti muinaselanikele ilmselt jumal ise, kes kohutava hävitava väe ja kõrvulukustava kõuemürinaga maale laskus. See sündmus muutis kindlasti selle sündmuse kaasaegsete maailmapilti lähedal ja kaugemalgi, õigemini oli selle maailmapildi osa. Kindlasti on säilinud selle sündmuse kajastusi Vahemere ääres või isegi Pärsias. Käesoleva uurimuse ülesanne ei ole siiski nende jälgede uurimine. Püüan selgitada Taarapita nime tähendust ja päritolu. Saan selles toetuda Uku Masingu uurimustele (1939, 1995), Lennart Mere mõttelennule (1976), Ants Viirese ülevaatele (1990), aga ka näiteks Aleksandr Kotljarevski ammusele ettekandele Õpetatud Eesti Seltsis (1871). ${ }^{1}$

Järgnevas analüüsis vaatan kõigepealt veel kord üle Taarapita esinemise Liivimaa kroonikas ja rekonstrueerin seal esineva Taarapita nimekuju. Näitan, et Taarapita retseptsioon tänapäeva maailmas on kahetine: ühelt poolt väärtõlgendused (öökullijumal) ning teisalt kui kõrvaltegelane slaavi jumalate panteonil. Seejärel uurin Taara võimalikke seoseid slaavlaste, germaanlaste, keltide ning altai ja ugri rahvaste jumalatega ning küsin, missugused teated on meil Taarapitast enne Henrikut. Lõpuks võtan lähema lingvistilise vaatluse alla Taarapita nime esimese poole taara ja teise poole pita ning katsun need uuesti kokku panna, et leida Taarapita võimalikku tähendust.

Oma jumala - Taarapita - nime teema on meile väga tähtis, sellest tuleb ikka ja jälle kirjutada. Vaevalt saame me kunagi täieliku kindlusega ütelda, mida tähendas ja osutas Taarapita siin maal enne ristisõdijate saabumist. 
Urmas Sutrop

\section{Taarapita Henriku Liivimaa kroonikas}

Henriku Liivimaa kroonikas nimetatakse Taarapitat viis korda. Harilikult arvatakse, et see nimi tähendab appihüüdu Taara avita! (vt Viires 1990). Nii tõlgendab seda praegugi veel Tartu Ülikooli vana kirjakeele töörühm (Ehasalu jt 1997: 24). Sellist käsitlust põhjendatakse harilikult sellega, et labiaalid $p$ ja $v$ võivad kergesti teineteiseks üle minna.

Lennart Meri kirjutab: "Taarapita ei tähenda appihuikamist, vaid "Taara pikset". Muistne pitkne ... käibis tabulise sõnana niihästi mao kui pikse tähenduses" (1976: 107). Enne, kui hakkan seda väidet kinnitama või ümber lükkama, vaatan, missugused Taarapita nime kujud on Henriku kroonika meie päevini säilitanud.

Taarapita nimi esineb Liivimaa kroonikas alates XXIV peatükist (aastast 1220 kuni kroonika lõpuni 1227). Kroonika algkäsikirja säilinud või vähemalt leitud ei ole. Kõige vanem ja ka täpsem kroonika ümberkirjutus, nn Codex Zamoscianus (Z) pärineb 14. sajandi algusest. Kahjuks ulatub see ainult XXIII peatüki 8. jaotuseni. Seega on kõik viis Taarapita esinemist rekonstrueeritud teiste vähemtäpsete ja hilisemate käsikirjade järgi.

Säilinud käsikirjad jaotatakse interpoleerimata ja interpoleeritud käsikirjadeks. Kõik säilinud käsikirjad peale Codex Zamoscianus'e on tagasiviidavad oletatavale käsikirjale X 14. sajandi lõpust või 15. sajandi algusest. See oli ilmselt sõltumatu käsikirjast Z (joonis 1). Allikate ja käsikirjade kohta lähemalt vt Albert Baueri sissejuhatust kroonika saksa väljaannetele (Arbusow \& Bauer 1955, 1959).

Leonid Arbusowi ladinakeelse editsiooni aluseks on käsikiri Z, selle lünkade puhul ning pärast XXII 8, kui Z lõpeb, käsikirjad $\mathrm{R}$ ja $\mathrm{S}$, arvestatud on ka käsikirju $\mathrm{T}$ ja o. Arbusowi editsiooni 2. trükis on märkustena esitatud ka lahkuminekud Taarapita nimekujus erinevates kroonika käsikirjades (Arbusow \& Bauer 1955). Erinevates käsikirjades leiduvad Taarapita nime kujud on esitatud tabelis 1.

Taarapita nimekujudest torkab kõigepealt silma $m$-lõpuline Tharaphitam "ut Christum predicent, ut Tharaphitam, qui deus fuit Osilianorum, eiciant" (220; et nad Kristust kuulutaksid ja Tharapita, kes oli saarlaste jumal, välja viskaksid; 194b). ${ }^{2}$ Siin on 
Henriku käsikiri

Arhetüüpne käsikiri 13. sajandist

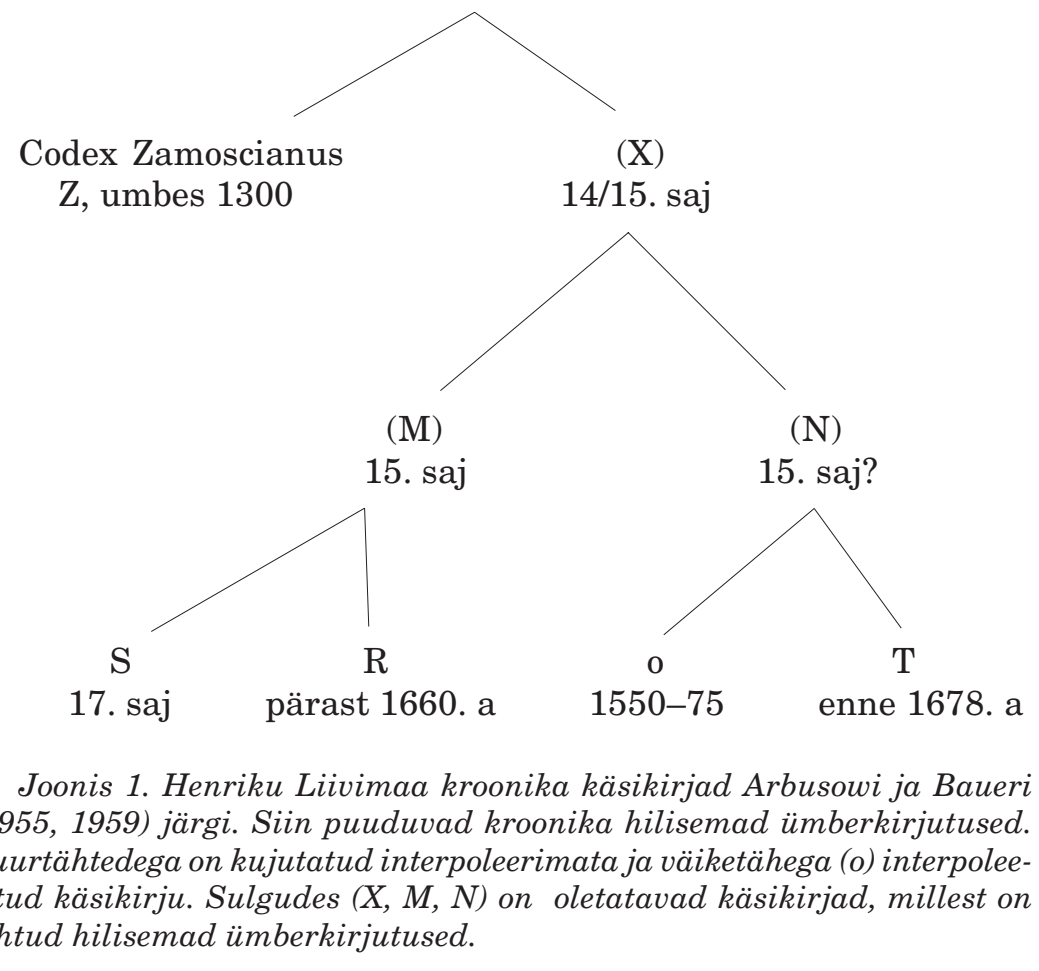

\begin{tabular}{|l|l|l|c|c|}
\hline \multirow{2}{*}{ Lk, rida } & \multirow{2}{*}{ Tekstis } & \multicolumn{3}{|c|}{ Märkustes } \\
\cline { 3 - 5 } & & $\mathrm{T}$ & o & $\mathrm{S}$ \\
\hline \hline 175,10 & Tharapita & & & \\
\hline 218,27 & Tarapitha & Therrapita & & \\
\hline 220,30 & Tharaphitam & Tarrapitta & Tarapitha & \\
\hline 221,14 & Tharapitha & & & \\
\hline 222,2 & Tharaphita & Tharrapitta & Tharapitha & Tharaphita \\
\hline
\end{tabular}

Tabel 1. Taarapita nime kujud Liivimaa kroonika erinevates käsikirjades Arbusowi ja Baueri (1955) teksti ja kommentaaride järgi. 


\section{Urmas Sutrop}

kunagine kroonika ümberkirjutaja lisanud nimele lihtsalt ladina keele naissoo akusatiivi lõpu -am (phita : phitam).

Käsikirjas T üks kord esinev kuju Therrapita, kus esimeses silbis on $a$ asemel $e$, on ilmne ümberkirjutusviga, samas käsikirjas mujal on ikka $a$. Muidu iseloomustab selle käsikirja nimekujusid kummaski nime pooles teise silbi konsonandi kahekordistamine (Tarrapitta). Võime rahulikult kõik käsikirja T kujud kõrvale jätta.

Edasi on oluline $h$ esinemine. See esineb kõigis nime kujudes (v.a Tarrapitta (T), mille me juba kõrvale jätsime) kas nime esivõi tagaosas või kummaski nime pooles. Taarapita nime esimeses pooles on $h$ puudumine ilmselt juhuslik. Seega on kroonikas nime esimene pool Thara-. Nime teise poole varieeruvus on suurem: pita, pitha, phita. Kuid siin on juba võimatu otsustada, kas tähemärk "h" on kandnud mingit tähendust. Seega võime valida kuju -pita ja kokku kasutada Tharapita, nagu see esineb esimest korda kroonika tekstis $(175,10)$. Siingi on $h$-l tähendus ainult siis, kui Thara- vastab kuidagi skandinaavia jumalale Pórr, s.t kui laenu suund oleks Skandinaaviast meile. Isegi sellel juhul oleks eesti hääldus pidanud olema $t$ : taara-, mitte $t^{h}: t^{h} a a r a-$ (nagu ka kuld, soome kulta < gooti gulb). Kui t: taara- oleks olnud kuidagi aspireeritud, poleks see saanud olla saarlaste oma suur jumal, vaid skandinaavlaste suur jumal, kelle nime püüdlikult jäljendati. Aga kroonikas on ju juttu saarlaste suurest jumalast: "ubi erat mons et silva pulcherrima, in qua dicebant indigene magnum deum Osiliensium natum, qui Tharapita vocatur, et de illo loco in Osiliam volasse" (175; kus oli mägi ja väga ilus mets, kus, rääkisid kohalikud, olevat sündinud saarlaste suur jumal, keda kutsutakse Tharapitaks, ja sellelt kohalt Saaremaale lennanud; 155b.)

Eelneva arutelu põhjal kasutan eesti keeles nimekuju Taarapita (vajadusel võib kasutada ka Tharapita). ${ }^{3}$ Wiedemanni sõnaraamatus on märksõnad $t \bar{a} r$, omastav $t \bar{a} r a$ 'eine mythologische Person, Geist', Tōr, omastav Tōru (lõunaeesti Tōro) 'Name einer Gottheit' ning Tórapitta, omastav Tórapitta 'Name einer Gottheit'.

Nüüd on meil võimalik analüüsida nime Taarapita ning Lennart Mere interpretatsiooni, et see võib tähendada Taara pikset:

1) Thara- on nimetavaline kuju. Apokoop (lõpukadu) ei ole veel eesti keeles toimunud. Seega 13. sajandi alguses oli nimetav Taara, mitte *Taar $\left({ }^{*} t \bar{a} r\right)$. Sel juhul oleks meil tegemist rinnastava liitumisega Taara+pita, mispuhul võiksime oletada, et Taara on ikkagi skandinaavia Thor ning tundmatut on seletatud tuntuga. 
Seega võiksime oletamisi arvata, et Taarapita tähendab "Thorpikset";

2) Thara- on siiski omastavaline kuju. Paul Johansen tuli Taani hindamisraamatu liitseid kohanimesid analüüsides järeldusele, et eesti keelest oli $n$-lõpuline omastav 13. sajandi alguseks juba kadunud (1933: 293). Ainult siis, kui Taarapita nimes on tegemist omastavalise liitumisega, on võimalik interpretatsioon "Taara pikne". Sellele võimalusele räägib aga vastu Alo Rauna ja Andrus Saareste arvamus, mille järgi hakkas sõnalõpuline $n$, mis ei olnud inflektsionaalne morfeem, nõrgenema alles 15 . sajandil. Nende järgi hakkas omastava käände lõpu - $n$ nõrgenema ja kadus täielikult alles järgneval 16. sajandil (Saareste \& Raun 1956: 61jj).

Kaitstud positsioonis - liitsõna keskel - võis omastava käände lõpp - $n$ püsida kauemgi (näiteks sõnas maantee praegusenigi). Juhul, kui omastava lõpp - $n$ polnud veel eesti keelest kadunud, oleks Liivimaa kroonikas pidanud leiduma kuju *Tharanpita. Seega ei ole võimalik kindlalt väita, et Taarapita oleks samane Taara piksega.

"Taara pikne" on samasugune väljend nagu "Jumala välk". Kuid nagu "Jumala välk" ei saa olla jumala nimi, välk osutab ainult jumala ühele atribuudile, nii ei saa ka "Taara pikne" olla jumala nimi, pikne saab selles väljendis olla ainult jumala (Taara) atribuut.

Ainus võimalus pikse juurde jääda oleks tunnistada rinnastavat liitumist loeteluna "Taara, Pikne". Nagu ma juba ülal märkisin, viiks see automaatselt selleni, et Taara on Pórr, ning sellele on arusaadavuse huvides juurde lisatud tõlge. Täielik Taarapita tõlge oleks siis "Pikne, Pikne". See on aga jällegi väheusutav, sest siis poleks Taarapita mitte saarlaste suur jumal, vaid hoopis skandinaavlaste jumal.

\section{Öökullijumal ja sarapuuhiis}

Martti Haavio (1970) näitab õigesti, et Taarapita ei tähenda sõjahüüdu Taara avita! Samas püüab ta aga tendentslikult tõestada, et ei eestlastel ega saarlastel polnudki oma jumalat. Ta võtab aluseks Henriku kroonika lõigu "Gaudet exercitus christianorum, exclamant, Deum exorant. Clamant et illi, gaudentes in Tarapitha suo. Illi nemus, isti Iesum invocant ..." (218; Kristlaste vägi rõo- 


\section{Urmas Sutrop}

mustab, nad karjuvad, paluvad jumalat. Ka need karjuvad, rõomustades oma Tarapitha üle. Ühed hüüavad appi hiit, teised Jeesust; 192b). Seda lõiku tsiteerib Haavio kahe erinevusega: esiteks väheoluline erinevus hi (p.o isti) Iesum invocant ning teiseks kasutab ta nimekuju Taraphita. Sellist nimekuju ei esine aga üheski Liivimaa kroonika käsikirjas (vt tabel 1). Haavio samastab tsiteeritud lõigus kasutatud nimekuju Taraphita ja ladina nemus'e 'hiis, püha mets' ning annab tõlgenduse, mille kohaselt Taarapita tuleks hoopis lugeda Tarap-hita, mis tähendavat sarapuuhiit (liivikeelne taràs 'sarapuu' + *hitta (*hitto, hitte, hiisi-) 'hiis, ladina nemus'). Seega rõõmustanud need (eestlased) oma sarapuuhiie üle, mis olnud püha paik, ja pärast hüüdnud oma hiit appi (Haavio 1970). Sellist tõlgendust tuleb samuti nagu järgnevatki linnujumala tõlgendust lugeda väärkäsitluseks.

Tänapäeva maailmas tuntakse Taarapitat enamasti öökullijumalana, kelle nimi olla Tarapila (Tharapila). Näiteks on mahukas jumalate käsiraamatus looma-ja linnujumalate rubriigis lühiartikkel - Tarapila: An Estonian owl god (Leach 1992: 267). Siiski ei ole tegemist käsiraamatu autori ja toimetajate jaburusega. Selline tõlgendus ulatub eelmise sajandi esimesse poolde. Tsiteerin siin lõiku Jacob Grimmi saksa mütoloogia lisaköitest (Grimm 1965: III, 35 ):

Soome Tharapita on välja loetult Tharapila (Klemm 3, 121). Castrén (215) peab seejuuures silmas bild [pilt], Renvalli järgi Tharapilla kassikakk, eesti torropil (verhandl. 2, 92). Jusleni järgi pöllo bubo (284) ja tarhapöllo samuti bubo (373). ${ }^{4}$

Keeleajaloo põhjal on selline tõlgendus täiesti alusetu. Mart Mäger kirjutab: "Rahvas arvab kakulised kullide hulka ... Soome keelest laenati tarapöll (< tarhapöllö), millega ühte kuulub eesti päll 'öökull', tänapäeval juba ununenud nimetus" (1994: 199; võrdle ka Mäger 1967: 98). Seega pole varemalt meil öökulle niimoodi tarapöll - nimetatud. Mart Mägra järgi tehakse meil mõnikord vahet harilike öökullide ning kassikaku kui kõrvadega öökulli vahel. Kassikakk on ladina keeli Bubo bubo. Soome tarha 'aed', eesti tara, on balti laen (tara $<$ tarha $<{ }^{*}$ tarša $<$ balt.: leedu dar̃ žas. See tõlgendus viitaks osaliselt Taara nime balti päritolule. Ka see ei pea paika.

Linnujumala tõlgendus võiks toetust leida Breemeni Aadamalt, kes kirjutab, et Aestlandi (Ästlandi, Estlandi) saare elanikud 
austavad draakoneid ja linde, kellele nad elusaid inimesi ohverdavad, keda nad kaupmeeste käest muretsevad pärast seda, kui nad on põhjaliku hoolikusega üle vaadatud, et nad kehalt ilma vigadeta oleksid, et draakonid neid ära ei põlgaks (Adam von Bremen 1986: 267 ja 1987: 327). ${ }^{5}$ Ning eks lennanudki ju Taarapita [Ebavere või Vaivara] mäelt Saaremaale. Jacob Grimm esitas 19. sajandi keskpaiku küsimuse - Kas linnu kujul? (Grimm 1965: I, 62). Küsimuse juures on veel Taarapita trükitud kujul Tharapita. Hiljem on see loetud trükiveaks, mida tulevat "õigesti" lugeda Tharapila (Grimm 1965: III, XIV). Ants Viirese järgi on Taarapita kui linnujumala müüdi autor Johann Leonhard von Parrot, kes selle oli esitanud 1828. aastal (Viires 1990: 1412).

Saksa mütoloogia ingliskeelse tõlke (Grimm 1883: II, 669) ja raamatu Linnujumalad (de Kay 1898: 172-173) abil ongi väärkäsitlus eesti öökullijumalast Tarapilast (Tharapila) maailma rändama läinud ja elab oma iseseisvat elu.

\section{Taarapita slaavi panteonil}

Aleksandr Kotljarevski pidas 11. märtsil 1870 (vkj) Õpetatud Eesti Seltsi 371. istungil ettekande "Eesti jumalus kui külaline Rügeni saarel" (Kotljarewski 1871: 36-39). Selles ettekandes on mitu meile olulist tulemust ja järeldust.

Kotljarevski näitab, et Henriku Liivimaa kroonika Taarapita on identne Knytlingasaga's nimetatud jumalusega Turupid. Sellest ta järeldab, et lugemisviis Tharapitha on õige [ilmselt siis mitte *Tharapila; see, et ta nime teises pooles loeb välja $h$, meid ei häiri]. Ta usub, et see nimi on skandinaavia jumala Thôr nime ja kuju vastukaja (Wiederhall). Kogu nime tähendus tuleks tema järgi lugeda Tar-awitaja, kus pitha < awita abita.$^{6}$

Probleemiasetust on juba kirjeldanud Uku Masing oma artiklis "Taara päritolust" (1939). Saxo Grammaticus nimetab Rügeni saarel kolme slaavi jumalat, kelle kujud taanlased aastal 1168 või 1169 hävitasid (Waitz 1964). Poreviti või Porenuti asemel nimetab Knytlingasaga samas kontekstis jumalat Turupið (Jónsson 1954).

Turupið ei sobi slaavi panteonile. Paljud slaavi mütoloogia uurijad lähevad sellest vaikides mööda. Teine traditsioon alates Kotljarevskist seostab Turupiði "soome" Taarapitaga. (Samas vaikivad ka soome uurijad soome mütoloogias Taarapita maha, kuna see 


\section{Urmas Sutrop}

ei sobi jälle neile.) Ma jätan praegu vaatluse alt kõrvale arvamused selle kohta, kuidas Turupið võis Rügenile sattuda. Masingule pole mul ka suurt lisada.

A. Brückner kirjutab: "auch ein finnischer Gott, Tarapita, ist hier als Turupit eingeschmuggelt" (1925: 521). Ühes prantsuskeelses religiooniajaloos üteldakse: "Turupit n'est très probablement que le dieu finnois Tarapita" (Clemen 1960: 401). Või jälle „Turupið, hinter dem man einen finn. Tarapita vermutete” (Reiter 1973: 192). Jaan Puhvel kirjutab oma võrdleva mütoloogia õpikus: "Turupit resembles the god Tarapita attested for the Estonian island of Osilia in the Livonian Chronicle of Henricus Lettus" (1987: 232). "Turupit sarnaneb Saaremaa Tarapitaga Liivimaa Henriku kroonikas" (Puhvel 1996: 235). Seejuures on lausa sümptomaatiline, et piirdutakse Turupiði ja Taarapita sarnasuse märkimisega, püüdmata nende võimalikku samasust tõestada või ümber lükata. Ka Grimmi Saksa mütoloogia joonealuses märkuses võrreldakse Taarapitat Turupiðiga (Grimm 1965: I, 62, märkus 2).

Slaavi jumalanimedele on iseloomulik teonüümiline segment -vit. Selle kohta vaata näiteks (Leger 1896). Ka Knytlingasaga's on Turupiði kõrval Rinvit ja Puruvit. Tavaliselt esitatakse Turupið kujul Turupit (nii ka Uku Masing ja Lennart Meri). Turupit on võetud Knytlingasaga ladina tõlkest ja on/oli trükitehnilistel põhjustel kergemini kasutatav. Tegelikult on latiniseeritud kuju eksitav, kuid sellest allpool.

Oletame nüüd, et segmendid -vit ja -pita on identsed. Üleminek $p \sim v$ oleks väga loomulik (nagu ka oletatud abita $\sim$ awita) ning -vit > *-pit >*-pita; a lisamisega muutub segment lihtsalt vokaaltüveliseks nagu enamik läänemeresoome sõnu.

Kuni viimase ajani puudus rahuldav etümoloogia slaavi teonüümilisele segmendile -vit. Selle on andnud alles V. N. Toporov (1989: 36). Ta analüüsib nimetusi Zwantewit/h/, Svantavit, Szuentevit jt. kui *Sveto \& *vitb ning kirjutab, et element *vitb põhjustab uurijatele palju raskusi, ning harilikult määratletakse seda kui 'isand', 'peremees' viitega kirikuslaavi sõnale домовить 'оเкобєб$\pi \circ \tau \eta \varsigma$, pater familias'. Toporov peab niisugust käsitlust lihtsustavaks ning pakub segmendile *vitb indoeuroopa etümoloogia.

Toporovi järgi $*$ vitb $<*$ viktb, kus $k$ ja $t$ on assimileerunud ning *viktb tuleb omakorda indoeuroopa *ueik-t või *uîk-t-tüvest *ueik'elujõud, tugev jõu väljendus', aga ka 'ohver, pühendamine'. Siia juurde toob ta näiteks ladina kognaadi victima 'ohvriloom, tänu- 
või lepitusohver', mis samuti tuletatud $t$-elemendiga tüvest *vik$t i$ - või *vik-tu-. Meid huvitava slaavi teonüümilise segmendi etümoloogiline rida oleks järgmine: -vit $<* v i t b<* v i k t b<* v i k-t u-$.

Tänapäeva vene keeles ei ole näiteks enam häälduses vahet, kas -vit või - vitb, kuid 12. sajandil kõlas slaavi $t$ redutseeritud $u$ (ъ) ees väga tumedalt. Nüüd jõudsimegi selleni, miks latiniseeritud kuju Turupit on väga eksitav: sellisel juhul on $t$ segmentides -vit ja -pit (-pita) sama. Tuletame nüüd veel kord meelde Knytlingasaga jumalate triaadi Rügeni saarel - Rinvit, Turupið ja Puruvit. Me näeme, et nende nimede lõpusegmenti on tajutud erinevalt. Slaavi tumedakõlaline - vitb on edasi antud kui -vit ja sellest oluliselt erinev -pit(a) kui -pið.

Seega võime oletuse, et segmendid -vit ja -pit(a) oleksid identsed, kõrvale jätta ning kindlalt väita, et -pita ei ole slaavi päritolu. Samuti annab ülalöeldu meile lisaargumendi selle kasuks, et 12. sajandil oli Rügeni saarel tõesti saarlaste suure jumala Taarapita kuju - Turupið. ${ }^{7}$

Hiljuti on Leszek Moszyński püüdnud väita, et Rügenil leidus keldi mõjutusi ning et Turupit < *Taran-vitъ olevat moodustatud keldi piksejumala nimest Taranis (1992: 55). Sellise Turupidi nime tõlgenduse ja keldi mõjud Rügenil lükkab aga O. N. Trubačev kategooriliselt tagasi (1994a: 5, 1994b: 5-6).

\section{Taara ja germaanlaste Donar-Pórr}

Uku Masing kirjutab: "Nimetusest Taara on kunagi tehtud eestlaste ülijumalus, kuid siis hakkas ka ta langus. Ta topiti igalepoole ja tulemuseks oli, et hakati kahtlustama, kas ta üldse kuulub kuskile, ja kuigi polnud kahtlust, et eestlased muiste kedagi säärase nimega olendit tundnud, tõsteti küsimus, kas selline jumalus üldse on eesti algupära, kas ta pole mitte laenatud skandinaavia Thorrist. Küsimus on praegugi lahtine ja selle saaks vast otsustada kindlamini ainult siis, kui oleks kindel, kas skandinaavia sõnal on indogermaani etümoloogia" (1995: 47). Kõigepealt vaatan, missugusel kujul oleks saarlastel (eestlastel) olnud võimalik skandinaavia nimekuju laenata, ja teiseks näitan, et skandinaavia sõnal on indoeuroopa etümoloogia.

Tabelist 2 on näha, et ainsuses kasutatavatel juhtudel lõpeb nimi alati konsonandiga. Jumala nime kasutamine mitmuses, kus 


\section{Urmas Sutrop}

akusatiiv lõpeb tematiseeritud tüvevokaaliga ja omastav käändelõpuga $a$, on aga äärmiselt vähetõenäoline. Raske on ette kujutada, et muistsed skandinaavlased oleksid oma jumala poole pöördunud mitmuses. Veelgi vähemtõenäoline on, et keelekontaktide puhul tuleks arvesse jumala nime mitmuslik kasutamine. ${ }^{7}$ Laenamise alusena saaksid kõne alla tulla ainult nimetav või objektikääne akusatiiv. Samuti on selge, et laenata sai seda nime ainult konsonanttüvelisena.

\begin{tabular}{|l|l|l|}
\hline Kääne & Ainsus & Mitmus \\
\hline \hline nimetav & bór-r & bór-a-r \\
\hline akkusatiiv & bór- $\varnothing$ & bór-a- $\varnothing$ \\
\hline omastav & bór-s & bór- $\varnothing-\mathrm{a}$ \\
\hline daativ & bór-i & bór- $\varnothing-$-um \\
\hline
\end{tabular}

Tabel 2. Nime Pórr (tematiseeritud a-tüvi mitmuses, meessugu) käänamine vanaislandi keeles. Käändelöpud on eraldatud sidekriipsudega, märk $\emptyset$ tähistab, et lõpp või tüvevokaal puudub.

Vokaaltüvelisena laenamine oleks mõeldav, kui muistsed skandinaavlased oleksid sõna bórr kasutanud apellatiivselt soonimena tähenduses 'jumal, jumalad'. Selline apellatiivne tähendus võis aga nimetusel bórr olla ainult skandinaavlaste jumalakultuse väga varajasel arengustaadiumil. Varasem Pórr'i nimekuju oli Punarr, kuid sellest ei tule Taara laenamine kõne allagi. Seega ei saa Taara, kui see on laen põhjagermaanlastelt, olla väga iidne. Kas Taara on laenatud kujust Pór(-r), jätan praegu lahtiseks, enne vaatan sarnaste nimede esinemist keltidel, altai ja ugri keeltes. Praegu vaatame nime Pórr indoeuroopa etümoloogiat.

Kui anglosaksid võtsid 300. aasta paiku vastu rooma kalendri, nimetasid nad viienda päeva ladina Jovis dies'i 'Jupiteri päev' järgi Punresdæg'iks, sest punapealine germaani piksejumal Pórr vastas funktsionaalselt Jupiterile, Zeusile, Indrale jt indoeuroopa piksejumalatele (Cotterell 1986: 187). See nädalapäeva nimetus on pea kõigis germaani keeltes tänapäevani säilinud: rootsi, taani Torsdag, vanaskandinaavia Pôrsdagr, inglise Thursday, keskalamsaksa dunredach, donerdach, hollandi donderdag, vanaülemsaksa donarestag, saksa Donnersdag. Germaanlaste panteonil troonib ühisgermaani piksejumalana Donar ja põhja pool Pórr. Sageli 
ühendataksegi käsitlustes need nimed Donar-Pórr (Beck 1986; Handwörterbuch 1929/1930: 307 - 345). Seega funktsionaalselt, tähenduslikult on Donar ja Pórr samased. Kas ka etümoloogiliselt?

Kahesilbilised nimetused, nagu anglosaksi Thunaer ja vanainglise Punor, on tagasiviidavad kujule *PunaraR (nomen agentis verbaaltüvest) ja ühesilbilised põhjala nimetused, vanaislandi Pórr ja ruuni-taani Pur, vastavad kujule * PunraR (apellatiivselt tähendus 'pikne'). Erinevad autorid on detailides rekonstrueerinud veidi erinevaid algvorme. Uku Masing arvab, et just katsete mitmekesisus rekonstrueerida nime Pórr algkuju näitab indoeuroopa etümoloogia puudumist - "siin on midagi katki" (1939: 6). Interpretatsioonide mitmekesisus näitab siiski uurimisteema olulisust ja uurijate erinevaid arusaamu. Nagu me kohe näeme, tuletatakse Pórr ikkagi ühest ja samast indoeuroopa tüvest.

Kui võrrelda nimesid Donar ja Punar-r, siis ka nende samasus on ilmne. Osutatud verbaaltüvele vastab ladina vorm tona-re, tono'müristama, mürisema, kärgatama, raksuma, põruma, kaikuma' (Walde-Hofmann 1954: 690 - 691; Meyer-Lybke 1972: 728, nr 8778). Skandinaavia etümoloogiate kohta vaata veel norra-taani etümoloogilist sõnaraamatut: Torden, Pôrr, indoeuroopa tüvi *(s)ten (Falk \& Torp 1960: 1273jj); islandi etümoloogilist sõnaraamatut: 1. sten-, ten- (indoeuroopa tüvi), Pórr (Jóhannesson 1956: 872) ja muinasskandinaavia etümoloogilist sõnaraamatut: órr, indoeuroopa tüvi (s)ten (de Vries 1962: 618).

Seega pikse ja piksejumala nimetus on germaanlastel tagasiviidav indogermaani tüvele (s)ten- 'von lauten Geräuschen: donnern, rauschen, dröhnen, stöhnen' (Pokorny 1959: I, 1021), sten-, ten- 'von Lauten Geräuschen: donnern, rauschen, brausen, dröhnen, stöhnen' (Walde-Pokorny 1930: II, 626jj) või steno 'groan, moan' (Mann 1984-1987: 1284). Tüvel on olemas vasted ka indoiraani keeltes: stan 'roar', stánati 'roars', stanáyati 'thunders' jt. (Turner 1966: 788), aga ka slaavi keeltes, nt vene стенать 'oigama, soiguma, halisema' ja стон 'oie, oigamine; soigumine' (Vasmer 1958: III, 10 ja19).

Seega ei saa kahtlust olla selles, et Pórr on sama mis Donar ning et neil on olemas täiesti aktsepteeritud ja rahuldav indoeuroopa etümoloogia. Seega ei saa skandinaavia Pórr olla laen läänemeresoome keeltest. Algne indoeuroopa tüvi kolina, mürina, oigamise ja soigumise kohta on hakanud germaani keeltes tähistama 
Urmas Sutrop

pikset ja see omakorda on andnud piksejumala nime Donar = Pórr. Uku Masingu küsimus on saanud seega vastuse.

\section{Keldid, germaanlased ja Taara: keltide Taranis ja Tanaros ning germaanlaste Donar-Pórr}

Keldi aladelt on teateid piksejumala Taranise (Taranus, Taranucus, Taranucnus) kohta, kõik teated ainult kontinendilt, ja piksejumalast Tanarosest, teated Britanniast ning Pliniuse kirja pandud gallikeelne Tanarus, mis oli Po jõe nimetus Põhja-Itaalias (tähenduses 'kohisev, mühisev, mürisev').

Jaan Puhvel peab galli piksejumalat Taranist $u$-tüvelise *tara$n u$-, vanaiiri ja kõmri 'kõu' kognaadiks. Ta nendib, et taran- on metateetiline $^{9}$ tüvega tanar-, mis leidub ladinakeelses raidkirjas $\mathrm{I}($ ovi) $\mathrm{O}$ (ptimo) $\mathrm{M}$ (aximo) Tanaro ning on samane germaani tüvega *thunar- 'kõu' (1987: 169, 1996: 173).

Keldi piksejumalale Taranisele pühendati tapetute pead või põletati ohvriks inimesi (Leach 1992: 222). Tanaros, Tanarus oli lokaalne piksejumal, keda on samastatud Jupiteriga (vt I O M Tanaro ülal). Tema kohta on teateid Gallia ja Briti aladelt (Leach 1992: 221).

Keldi piksejumala(te) Taranise, Tanarose käsitlemisel ja tõlgendamisel on kaks traditsiooni (vt Vendryes 1981: T-143). Esimese järgi on Tanaros identne germaani jumalaga Donar-Pórr ning neil nimedel on ühine etümoloogia (*PunaraR on etümoloogilises vastavuses keldi tüvega *tonar-(Tanaros)). Selle vaate järgi on tüvi *toran- (Taranis) eelmise suhtes metateetiline (*tonar > toran-). Seda vaadet jagab ka Jaan Puhvel. Selles aga kaheldi juba möödunud sajandil (Stokes \& Bezzenberger 1979: 122).

Teine traditsioon peab aga nime Taranis keldi oma nimeks, mida tuleb vaadata lahus germaani jumalatest ja etümoloogiast. Pikne, kõu on vanaiiri keeles torainn, uusiiri toìrneach (aga torann 'müra'), kõmri ja bretooni taran. Samuti vanaiiri tairm 'müra'; leedu tarti 'ütlema', kreeka $\tau$ coos 'läbitungiv (müra jne)', siia ka Thorybos 'personifitseeritud müra'. Keldi piksejumala ja pikse etümoloogia indoeuroopa tüvest tor(o-s) ja kognaadid teistest indogermaani keeltest Walde-Pokorny (1930: I, 744) järgi on esitanud juba Uku Masing (1939: 14 jj). Siia juurde veel kord sama 
tüvi: tor-, toro-s 'vali, kuuldav; läbitungiv (heli)' (Pokorny 1959: 1088-1089). ${ }^{10}$

Selle traditsiooni järgi võib Tanaros siiski olla germaani jumalaperega seotud, kuid on ka võimalik vastupidine metatees *toran- > tonar-. Viimasel ajal peetakse kujusid Tanaros ja Taranis siiski üheks nimeks (Birkhan 1970: 313). ${ }^{11}$

Uku Masing oletab, et õigus on neil teadlasil, kes väidavad, et germaanlaste "Thor on laenatud gallialasilt" (1939: 10). Nagu me ülal nägime, oleks see ju võimalik, nagu ka see, et keldid oleksid oma jumala laenanud germaanlastelt. Selles ei ole aga täit selgust. Natuke edasi kaalub Masing võimalust, et nii keldi kui skandinaavia nimed on laenatud soome-ugri rahvailt (1939: 15).

Võimaluse, et skandinaavlased oleksid oma Pórri laenanud eestlasilt, jätsime juba kõrvale. Paul Ariste kirjutab: "Protoeuroopa substraati on nenditud peale läänemere keelte indoeuroopa, eriti just keldi ja germaani keeltest. Selle tõttu on läänemere, germaani ja keldi keeltes mõningaid ühiseid sugemeid" (1981: 10). Teisalt ei ole teada, et läänemeresoomlasil oleks olnud kontakte keltidega. Seega ei saanud ka keldid läänemeresoomlastelt midagi laenata. Ainus võimalus oletuseks, et Taara, Taranis-Tanaros ja Donar-Pórr moodustavad siiski ühtse etümoloogiaga ühtse jumalatepere, oleks oletada, et tegemist on muistsete keele- ja kultuurikontaktidega.

Varaste keele ja kultuurikontaktide puhul peame arvestama ka baski ja etruski keelega. Oletatakse, et baski keel on üks tänapäevani säilinud protoeuroopa keeli, mille levik on varemalt olnud palju suurem. Vanaeuroopa keelte hulka kuulub ka etruski keel, mille kirjalikke mälestisi on säilinud ajast enne Kristuse sündi. Nagu baski, nii on ka etruski keele puhul tehtud mitmesuguseid oletusi nende keelkondliku kuuluvuse kohta. Keeleteadlased on siiski aktsepteerinud, et mõlema puhul on tegemist isolaadiga.

Jaan Kaplinski on ühes ajaleheartiklis väitnud, et Taara võis olla muistne baski ja Põhja-Euroopa jumal (Sirp, 6. veebruar 1998, $\mathrm{nr} 5, \mathrm{lk} 7$ ). Selle tõestuseks toob ta baski kirjamehe Pío Baroja kasutatud baski jumalanime Urtzi Thor. Siin on tegemist nähtusega, kus baski jumalat Urtzi kõrvutatakse teisest kultuurist tuntud samaväärse jumalaga Thor. Baski keel Thori-nimelist jumalat ei tunne. Urtzi (Ortzi, Ostri, Ostiri) on aga baski jumalanimi, mis on tuletatud tähendusest 'taevalaotus, taeva heledus'. 12. sa- 


\section{Urmas Sutrop}

jandist on teada ülestähendus "Deum vocant Urcia"' [baskide] jumalat kutsutakse Urciaks' (de Barandiarán 1973: 548).

Etruski arvukate jumalate seas huvitab meid Tina (Tinia), kes vastab Jupiterile ja Zeusile. Tina oli taevane jumal, kes valitses kosmose põhja- ja kirdesegmentide üle. Siiski võis ta heita piksenooli igasse ilmakaarde, samas kui teistel jumalatel oli lubatud seda teha ainult kindlatesse suundadesse (Leach 1992: 68).

Eduard Hrkali järgi on etruskide päeva- ja piksejumal Tinia (Tin) roomlaste Jupiteri vaste. Ta tuletab jumala nimetuse algetruski sõnast $t i n$, mida ta seostab turaani ${ }^{12}$ sõnaga $t i n$, varasem tïn, mis tähendab vaimu (Geist) kõigis saksa keelele omastes tähendustes. Kuna aga ei ole selge etruski keele sugulus ühegi tänapäeva keelega, ei saa kindlalt uskuda ka seda etümoloogiat.

Kuna meil ei ole mitte mingit põhjust oletada, et protoeuroopa keel, mida kõneldi Läänemere ääres enne soome-ugri hõimude saabumist, oleks kuidagi olnud seotud etruskide või nende keelega, oli ülaltoodu ainult spekulatsioone võimaldav ekskurss või illustratsioon. Tuleb tõdeda, et puudub igasugune jälg, mis võimaldaks meil otsida substraadinähtuste hulgast võimalikku seost jumalate Taara, Taranis-Tanaros ja Donar-Pórr vahel.

Mõned autorid peavad siiski võimalikuks, et kunagi on olnud ühtne indoeuroopa piksejumal, kelle levik ulatus Euroopas Põhjalast kuni Armeeniani. Näiteks Joseph Karst seostab põhjala Pórriga (Thoriga) armeenia eelkristliku jumala Tork'i (Thorkh) ja peab neid identseteks (1931: $604 \mathrm{jj}$ ). Ta rekonstrueerib eelindoeuroopa pikse ja kõuetormi jumala *Thorqvin'i, kelle kujud oleksid siis Thor ja Thorkh. Pórr oleks seega lihtsalt apokopeeritud (lõpukaoline) vorm algsest kujust *Thorqvin. Karst arvab, et selle jumala kahvatu kujutis on ka illüüria-albaania drek (trek) 'kurat'. Ta tuletab piksejumalad indoeuroopa juurest $V_{\text {tro }}$, tork '(ilma)ring'. Seda etümoloogiat ei ole teised uurijad toetanud ja seda võib pidada ainult spekulatsiooniks. ${ }^{13}$

Meil pole siiski mingit alust oletada protoeuroopa substraadi ega Karsti oletatud indoeuroopa ühise piksejumala mõju ei Taara ega keldi või germaani piksejumalate nimede kujunemisele. Laiendame nüüd haaret ning vaatame altai ja teiste kaugete rahvaste sarnaseid (pikse)jumalate nimetusi. 


\section{Polüneesia ja altai jumalad}

"Meie oma nimetuse [Taara] võiksime asetada väga laialdasse seosesse, kuid kõik need loeteldavad sõnad erinevad vähemalt niivõrd palju, et ei saa öelda, kas eesti sõna on seoses nendega või olemata. Kõigepealt ostjaki [handi] Tôrâm, voguli [mansi] Toorm, Torim, tšuvašši Tora, türgi Tare [?], mongoli, turkmeeni, uiguuri, tatari Tängere, Tengri, Tenger, kirgiisi Tangri, jakuudi Tangara ning siis üheltpoolt sumeri di(n)gir, teisalt polüneesia Tangaroa," kirjutab Uku Masing (1995: 47). Jätan praegu handi ja mansi jumalanimed kõrvale (tulen nende juurde järgmises peatükis) ning peatun polüneesia ja altai nimedel.

Lugesin Marjorie Leachi (1992) jumalate teatmiku indeksist kokku, et selles on käsitletud ligikaudu 19200 jumalat ja jumalust, nendest algab T-ga 1750. Kui me jätkame uurimist, siis algusega Tar- on 41 nime, algusega Tor- 24 nime jne. Kuna jumalate arv maailmas on oluliselt suurem kui inimkeeltes kasutatavate häälikute arv, kohtame sarnaseid nimesid pelga juhuse tõttu väga paljudes maailma paikades, olgu siis Polüneesias või Aafrikas. Uku Masing nimetab polüneesia jumalaid ainult oma erilise kiindumuse tõttu polüneesia usundisse. Seepärast jätan praegu polüneesia jumalad rahule ja lähen altai jumalate juurde, kes on meile ja meie keelele lähemal.

Altai rahvaste ühine nimetus jumala jaoks on Tengri (Tenri). Islam on küll selle nimetuse praegu türgi ja mõnedes teistes keeltes pea täielikult kõrvale tõrjunud. Lisan mõned altai nimetused: türgi Tanr $1^{14}$ 'jumal', mongoolia тэнгэр 'taevas, taevalaotus, ilm, jumal, jumalus', тэнгэр дуу 'kõu', usbeki тангри 'jumal'. Mongoolia tenger tähendusest paistab juba altai jumalanimetuse algne tähendus - taevas. Sõna algne tähendus taevas oli väga lihtne, umbes nagu lausetes "Päike on taevas", või "Pilved katavad taeva". Sellisest algsest nimetusest ongi arenenud jumala üldine nimetus. Selline areng on väga tüüpiline. Lähema paralleelina võiks tuua soome-ugri *ilma 'ilm', millest on arenenud läänemeresoome taevajumala nimi Ilmarine. Paljudes altai keeltes on sõna *terri algne tähendus kaduma läinud ja asendunud tähendusega jumal või jumalus. Sõnal on ka adjektiivne tähendus jumalik või taevalik. Etümoloogiliselt arvatakse *teqri 'taevas' tulevat verbist, mis tähendas pöörlemist, muutumist (Roux 1987: 401 jj). Altai taeva- 
Urmas Sutrop

jumala Tengri kohta vaata ka Roux 1956, 1958; Räsänen 1969: 474

ja Clauson 1972: 523 jj.

\section{Handi ja mansi taevajumalad, karagassi taevas ja jumal ning saami kõu}

"Eesti jumala omapära tõestaks, kui kuskil mujal soome-ugri rahvaste juures leiduks taoline" (Masing 1939: 11). Võtame vaatluse alla handi ja mansi Taaraga sarnaste nimetustega taevajumalad ja vaatame, missugune võiks olla vastavate nimede päritolu.

Huvitavaid teateid jumala Tarom-Torom kohta leidub Peter Simon Pallase võrdlevas sõnaraamatus 1789. aastast (Pallas 1977: 2, 5). ${ }^{15}$ Mansi keele dialektides (nr 66-69) on jumal Taromъ / Sairengъ-Taromъ, Тarmъ, Тóromъ ja Torymъ. Ainult ühel juhul (nr 66) on sama sõna kasutatud taeva tähenduses: Táromъ. Handi keele dialektides ( $\mathrm{nr}$ 70-74; dialektis $\mathrm{nr} 75$ meid huvitav nimetus puudub) on jumal Тorómъ, Тогmъ, Тоromъ, Тоromъ ja Тоromъ / Tormъ; taevas kolmel juhul Toromъ, Numъ-Tóromъ ja ToromъIomъ. Ühel juhul (nr. 70) esines meid huvitav sõna ka pikse nimetuses - Tóromъ-Tutъ (siin lõpus peenendusmärgid). Pilt oleks selge ja ilus, kui äkki samojeedi keelte hulka kuuluvas nr 130 karassini (ilmselt karagassi) keeles ei oleks jumala Nobъ paralleelnimetus Teere ja samuti ka taeva Titъ paralleelnimetus teere.

Handi keele etümoloogilises sõnaraamatus antakse nimele Torəm tähendused '(kõrgeim, sagedasti kristlik) jumal, kaitsevaim, pühak, pühakupilt, ikoon; taevas, ilm, torm; maailm; aeg'. Selles raamatus tegelikult nime Toorem etümoloogiat antud ei ole, osutatakse ainult nime mansi kuju ja tähenduse samasusele. Huvitava detailina lisatakse, et vene keele murretesse on handi keelest laenatud nimetus тором (Steinitz $1966 \mathrm{jj}$ : $1471 \mathrm{jj}$ ). ${ }^{16}$ Mansikeelse nime Tårem [torem] tähendus on 'jumal, taevas; aeg, aastaaeg; maailm, ilm' (Munkácsi \& Kálmán 1986: 657 jj).

K. F. Karjalainen kirjutab, et nime Toorem päritolu on alles hämar. Tema järgi on seda nime seotud saami sõnaga diermes 'pikne', selles on nähtud türgi-tatari laenu sõnast taqri 'taevas' või vastavust ungari sõnadele árnyék 'vari' või terem 'ilmuma, tekkima, kasvama'. Ta oletab, et võimalik oleks esimene tõlgendus, aga seegi oleks tema järgi kahtlane (Karjalainen 1922: 292). Uku Masing arvab samuti, et handi ja mansi sõnad on ühenduses saami 
sõnaga diermes, millele ta rekonstrueerib võimaliku eesti vaste teerm. Küsimuse, kas Taara ja teerm on samased, jätab ta lahtiseks. Masing peab saami sõnades Dierbma, dierma 'vikerkaar, kõu' ja Diermes, dierbma 'kõu' olevat $m$-i sufiksiks (1939: 11 jj). Ivar Paulson märgib, et handi ja mansi Toorem päritolu on ikka veel selgitamata ning osutab seejuures Karjalaise tsiteeritud tööle (Paulson 1962: 61).

Esitan järgnevalt handi ja mansi Tooremile altai (türgi-tatari) etümoloogia. Handid ja mansid arvatakse olevat pärit LõunaUurali steppidest, kust nad 1. aastatuhande keskpaiku rändasid oma praegustele asualadele. Juba oma algkodus olid nad kontaktis altai rahvastega, oma praeguse asuala lõunapiiril säilis neil pidev kontakt tatarlastega. Paul Pelliot on näidanud, kuidas türgi tängrim 'mu jumal' (possessiiv) on kontraheerudes sisekao tõttu andnud nimekuju Tärim (Terim) (1914: 498, 1944). Sellega nõustub ka Gerard Clauson - tenrim 'mu jumal' ja terim 'kuninglik tiitel või pöördumisvorm' (1972: 524, 549).

Analoogia põhjal võib oletada, et handid ja mansid laenasid oma taeva ja jumala nimetuse Toorem mitte türgi kujust tängri 'taevas, jumal', vaid tenrim 'mu taevas, mu jumal', misjärel toimus sõnas sisekadu. Kuid laenamise alusena tulevad arvesse ka juba lühenenud possessiivsed kujud tärem või terem.

Hilisemad autorid peale Pallase karagassi jumalanimele Teere (teere 'taevas') enam ei osuta. Pallase enda varasema teate järgi aastast 1772 on karagassi jumal Tere ja taevas samuti Tere (1967: 375). Oma reisimärkmetes kirjutab ta, et "kõige tähelepanuväärsem on karagassi hõim, kes nagu koibalid ja motorid Jenissei ääres, on endi hulgas alal hoidnud õige vähe [mongoli ja tatari keeltega] segatud samojeedi keele, ja mis ainult 22 täiskasvanud meesterahvast koosneb. ... Nende [karagasside] uskumused ... on lihtsaimad maailmas; neil ei ole nõidu ega oma ebajumalaid, see-eest palvetavad nad taeva ja päikese [poole]" (1967: 304). ${ }^{17}$

Tõenäoseks võiks pidada, et karagassi Tere, Teere on hääbuva rahva suhteliselt hiline laen altai (tuva) keeltest. See vastaks altai kujule tärem, terem, kust on kadunud possessiivne sufiks $-m$. Elemendi $-m$ possessiivsufiksiks pidamise kasuks räägib ka see, et handi ja mansi keeles oli Tooremi nimede lõppu kirjutatud tugevdusmärk, mille kohta instrueeriti eelnevat konsonanti tugevamalt lugema [vt märkus 14]. Ka näiteks tänapäeva türgi keeles hääldatakse possessiivsufiks - $m$ alati selgelt välja. Ja ikkagi jääb 


\section{Urmas Sutrop}

lahtiseks handi ja mansi Tooremi seos saami pikse, kõue nimetusega Dierbma, Diermes, (tänapäeva koola-saami kirjakeeles Tiirmes), mille võimalikuks eesti vasteks Uku Masing rekonstrueeris teere- $m$. Kui me võrdleme seda nüüd karagassi sõnaga teere, siis tekivad meil uued küsimused ja kahtlused.

Oletame nüüd, et Teere ei ole mitte hiline altai laen, vaid uurali või uurali-altai päritolu sõna, ning see kuuluks kokku selliste nimedega nagu eesti Taara, saami Tiirmes (Diermes) ning handi ja mansi Toorem. Altai jumalanimetus on Tangri, Tanri 'jumal, taevas', ning see arvatakse tulenevat verbist, mis tähistas pööramist, muutumist. Kas oleks võimalik leida mõni sarnane juhtum soome-ugri keeltes?

Björn Collinder esitab uurali-altai ühiste tüvede hulgas (B nimekiri soome-ugri ja altai vastavustega, $\mathrm{nr} 58$ ) soome hiiri (*šinere) 'hiir' // mandžu singeri 'rott', golde singar ja tunguusi sinõrõkõon 'hiir, rott' (Collinder 1955:148). Uurali etümoloogilises sõnaraamatus esitatakse soome-ugri hiire nimetus kujul šine-re, kus -re oleks denominaalne nominaalsufiks (tuletab nimisõna nimisõnast), ning seatakse sellega vastavusse mandžu-tunguusi *sine$r e$ 'hiir, rott', seejuures peetakse võimalikuks mõlemat laenusuunda (Rédei 1988: I, 500; vaata ka Räsänen 1969: 109a ja 416a). Paralleel tengri / teqri $=>$ taara ja singere /sinere $=>$ hiir, gen hiire ${ }^{18}$ vahel oleks igati veenev, kui just ugri keeltes ei oleks hiire nime-

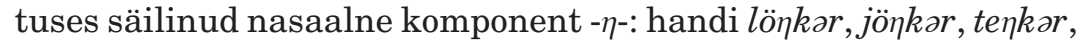

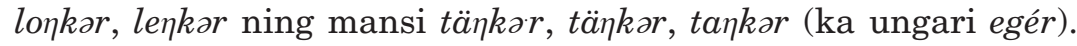
Seega võiks hiire näide veenda meid, et eesti taara ja saami teer$m$ (ning lõunasamojeedi karagassi tere, teere) vastavad altai kujule teqri, kuid selle näite abil ei saa me midagi ütelda handimansi taarem-toorem sõnade kohta.

Kui me vaatame uurali sõna nums 'ülem, taevas, jumal', siis saame seda analüüsida $n u-m z$, kus $n u$ on tähenduses 'ülemine osa, ülem' ja *-ms on denominaalne tuletusliide, mis muudab nimisõna uueks nimisõnaks (Rédei 1988: I, 308jj). Björn Collinderi järgi on $* m$ tüüpiline uurali nimisõna tüve determinatiivne liide, mis võib olla samane deverbatiivse nimisõna-moodustajaga ${ }^{*} m$ (Collinder 1960: 260, § 779; 266, § 799). Determinatiivne liide ahendab põhisõna, seeläbi muutub mõiste maht kitsamaks, sisu aga rikkamaks. Siin tasub kõrvutada teisi sõnu taeva ja jumala nimetamiseks: eesti jumal, volgasoome juma 'taevas, jumal', *-la on tuletusliide; eesti $i l m$ ja jumal Ilmarine, soome-ugri ilma 'taevas, 
ilm, jumal' ${ }^{19}$ Kui sõnas numz on - $m s$ selgelt tuletusliide, siis sõnades ilma ja juma võime ainult konstateerida, et sõna lõppsilp on -ma. Me võime oletada, et nasaalne komponent on kuidagi seotud uurali rahvaste jumalanimega, jumala mõistega, ning see võib esineda kas sufiksina või mõjutada mingil muul viisil jumala nime valikut. Võib-olla on meie esivanemad ümisenud jumalast mõeldes või rituaalselt teda pühitsedes. Kui see on nii, siis võiks see seletada $m$-sufiksi esinemise saami pikse nimetuses teer- $m$ ning handi-mansi sõnades taare- $m$, toore- $m$. Seda - $m$-elementi võiks pidada samasuguseks teonüümseks segmendiks nagu slaavlaste segmenti -vit.

Kuna algselt võis uurali ${ }^{*} m$-liide olla nii denominaalne kui

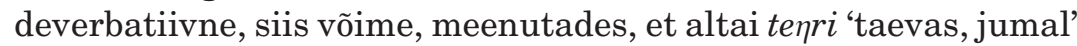
oli algselt verb, mis tähistas muutumist, pööramist, oletada, et juhul, kui meil on tegemist ühise uurali-altai verbaaltüvega *tenri, siis võis deverbaalne * $m$-liide moodustada sellest, mis taevas muutub ja pöörleb, taeva mõiste tenri- $m$ enda, samuti nagu verbitüvest või- (< *voi-) 'võima, võimeline olema' on moodustatud nimisõna võim. Hiljem hakkas see sõna tähistama jumalat, mõnel juhul ka pikset ning kaotas sisemise nasaalse komponendi. Eesti keeles võis see sõna kaotada ka deverbaalse liite * $m$ ning pärast mitmeid vokaalimuutusi jäigi järele ainult Taara. Meenutame veel, et nagu kõigile Põhja-Euraasia rahvastele, nii oli ka uurali rahvastele omane kujutlus pöörlevast ilmast, taevalaotusest. Siit on ainult üks samm kirjeldatud teed mööda vähemalt momendiks püsiva taeva ja jumala mõiste juurde.

\section{Taraconta ja Taara}

Võime küllalt suure tõenäosusega uskuda, et Knytlingasaga Turupið on saarlaste Taarapita. Nüüd võime küsida, kas meil on veel vanemaid kirjalikke jälgi Taarast või Taarapitast.

Aethicuse "Kosmograafias", mis on kirja pandud 8. sajandi keskpaigas või veidi hiljem, leiduvad saared Rifargica (Rifarica, Riffarrica) ja Taraconta (Wuttke 1991; Prinz 1993). ${ }^{20}$ Otto Prinzi toimetatud "Kosmograafia" uusväljaanne toetub Kurt Hillkowitzi kommentaaridele, kus mööndakse võimalust, et Rifargica (Rifarrica) insola võib osutada Eesti rannikule, kuid seda võimalust peetakse siiski vähetõenäoliseks (Hillkowitz 1973: 143-144, mär- 


\section{Urmas Sutrop}

kus 228). Jagan pigem P. Wieselgreni, Gustav Musta ja Lennart Mere arvamust, et Aethicuse Rifargica saar tähistab Rebala (Rävala) rannikuala (Wieselgren 1947: 114; Must 1951: 310; Meri 1976: 116).

Lennart Meri seostab Rifarrica "saarega" ka Taraconta saare ja oletab, et need asusid lähestikku. ${ }^{21}$ Ta pöörab tähelepanu ainult Taraconta nimetuse teisele poolele -conta ning seostab selle läänemeresoome sõnaga -kond, -kund tähenduses tervik. Samas ei pööra ta tähelepanu Taraconta nime esimesele poolele Tara- (Meri 1976: 116).

Taraconta kõrval esinevad „Kosmograafia” erinevates käsikirjades ka kujud Tareconta ja Tharaconta. Otto Prinz märgib oma väljaande joonealuses märkuses, et Taraconta on tundmatu nimi, mis tähistab saart, sellel asuvat suurt linna, samuti hõimu (rahvast) (Prinz 1993: 120, märkus 192). Teistsuguseid tõlgendusi Taraconta tähenduse kohta pakub Heinz Löwe, kes kaldub uskuma, et Taraconta saarel elasid türklased (1975: $133 \mathrm{jj}$ ). Varasemaid oletusi Taraconta tähenduse kohta leidub väljaandes Wuttke 1991: XXXI.

Kui Rifargica tähistab Rebala rannikuala, mis on väga tõenäoline, siis on vaatamata teistsugustele tõlgendusvõimalustele ülimalt tõenäoline, et Taraconta (Tharaconta) tähistab Saaremaad. Seda toetab ka asjaolu, et tuntud keelte abil ei ole Taraconta nime õnnestunud etümologiseerida, läänemeresoome keeled on ja jäävad enamasti uurijaile tundmatuks. Kond-lõpulised territoriaalsed üksused on eesti keeles üsna tavalised, näiteks üldised kihelkond ja maakond või konkreetsed varasemad maakonnad Nurmekund (Nurmegunde) ja Saaremaa lääneosas asunud Kihelkond (Kielkond, Kiligunde), mille jäänuk on tänapäeva Kihelkonna. Liide kond esineb ka hulka, kogu näitavates sõnades, nagu malevkond (väehulk), kümmekond, sadakond, perekond, hõimkond, põlvkond jt.

Sõna kunta ulatub kindlalt tagasi soome-ugri aega, aga võibolla isegi uurali aega, kus see tähendas sugu, sugukonda, sugupõlve või ühendust üldse (Rédei 1988: I, 206). Probleeme tekitab meile ainult see, et läänemeresoome keeltes kasutatakse kunta ka geograafilistes nimetustes. Peatun sellel küsimusel korraks lähemalt.

Mõnikord peetakse sõna kunta selle esinemise tõttu geograafilistes ning territoriaalsete üksuste nimedes germaani laenuks 
muinasskandinaavia sõnast hunda, tähendustega 'sada' ja 'rahvahulk, -jaotus', näiteks Ātt-hunda-land (Karsten 1936: 485). Sellist kunta tähendusnihet seletatakse ka lihtsalt germaani mõjuga läänemeresoome keeltele (Rédei 1988: I, 206), Farkas peab kunta sõna ka sellistes tähendustes, nt soome valtakunta 'riik', soomeugriliseks (1954: 330). Jacob Grimm näitab oma raamatus "Saksa õigusmuistised", et sõnal huntari (hundert 'sada') oli halduslikult kahesugune tähendus. Ühelt poolt vastas huntari suurema piirkonna (Tacituse pagi, germaani gaue, saksa Gau) alamjaotustele, teiselt poolt aga tähistas huntari mitte ühte väikest jaotusühikut, vaid ka väikestest jaotusühikutest moodustatud tervikut (Grimm 1989: 56 jj). Siit on hästi näha ka meie kihelkondade ja maakondade suhe. Ei ole kahtlust, et selline kunta kahetine halduslik tähendus on laenatud germaanlastelt.

Siit tuleneb meie jaoks veel üks oluline järeldus. Me saame ligikaudu hinnata maakondade ja kihelkondade vanust. Paul Johansen oletab uurimuses Saaremaa muinasskandinaavia nimetuse Ösel [<*Eysýsla] kohta, et kihelkonnad võisid Saaremaal ja Mandri-Eestis haldusüksustena tekkida Skandinaavia mõjul 9. sajandil (1950: 108). Kuna germaani haldusmõistele hunta (hun$d a$ ) vastab läänemeresoome kunta ( $k u n d a)$, siis saame oletada, et laen on küllalt varane ja dateeritav hiljemalt esimestesse sajanditesse pärast Kristuse sündi. Kui laen oleks olnud hilisem, siis oleksid läänemeresoomlased juba olnud õppinud selgeks $h$-hääliku ning hunta oleks ka läänemeresoome keeltes kõlanud hunta. Varaste laenude puhul on reeglipärane, et germaani $h$ antakse edasi $k$-ga, nt kana, kalju ja kaer. Seega võiks oletada, et kunta on geograafilistes ja haldusnimedes siiski laen germaani huntast, mida hõlbustas oma sõna kunta sarnane tähendus: inimesi hõlmav hulk, kogu, tervik. Sellise tõlgenduse poolt räägib eriti kunta kahetine halduslik tähendus - kihelkonnad ja neist koosnevad maakonnad. Sellised haldusjaotused võisid juba kasutusel olla Kristuse sündimise paiku või siis, kui Tacitus kirjutas oma Germania. Üheksandal sajandil kujunesid osast jaotustest Skandinaavia mõjul lepingutel põhinevad kihelkonnad.

Sõna kihl on laen germaani keeltest ( $<$ muinasgermaani *gisla, võrdle tänapäeva saksa Geisel 'pantvang') ja tähendab eesti keeles panti, lepet. Need tähendused on säilinud näiteks sõnas kihlvedu, ka kihla vedama (mingit kokkulepet sõlmima), kihlvedu pidama (st pikalt hoidma) - lepitakse milleski kokku ja see, kes peale 
jääb, saab pandi. Kihlused on toiming, mille puhul lepitakse näiteks kokku saajates, st pulmade toimumises. Ka kihluse puhul antav kihlasõrmus ei ole ju midagi muud kui pant. Kihelkonnad on lepingute ja pantvangide andmise kohustusega seotud territoriaalsed üksused, mis tekkisid sugukondliku korra lagunemise järel. Võrdle ka soome kihlakunta 'kohtuvõimu piirkond'.

Tulles nüüd tagasi Taraconta (Tharaconta) juurde, näeme, et kunta võis olla haldusnimetustes varem kui 9. sajandil, mil kujunesid kihel--st kihlkonnad. Me võime seda pidada omamoodi haldusreformiks, mille käigus kadusid vanad nimed ning tulid kasutusele uued. Seejuures on huvipakkuv detail, et Saaremaal muutus üldnimi kihelkond pärisnimeks Kihelkonna. Seda võiks seletada sellega, et varasem *Taarakond, mis ühendas suurjumala Taaraga seotud elanikud, muutus lepinguliste suhetega seotud kihelkonnaks Kihelkonna.

Aethicuselt pärinev nimetus Taraconta, Tharaconta - Taarakond - võis 8. sajandil tähistada kogu Saaremaad või ainult osa sellest. Viimasel juhul ei pidanud nimetus Taarakond hõlmama Kaali meteoriidi kraatri asukohta. Igal juhul võib oletada, et Taarakond vastas tervele Saaremaa lääneosale, selle hilisem nimetus alates 9. sajandist oli Kihelkond, mille jäänuk tänapäeval on Kihelkonna. Eesti kihelkondade ja Kihelkonna kohta on lähemalt lugeda töös Moora \& Ligi 1970: 65. Kohanime Kunda näiteid koos mõningate kirjanduse viidetega vaata ka Kettunen 1955: 23, nr. 55.

Järelikult on võimalik, et Aethicus jäädvustas saarlaste suurjumala nime Taara (Tara, Thara) juba 8. sajandi keskel, mil Saaremaad või selle läänepoolset osa võidi kutsuda Taarakonnaks (Taarakonta).

\section{Mida siis ikkagi Taara, pita ja Taarapita tähen- davad?}

Taara. Neenetsid tähistavad sõnaga tir pilve, näiteks tir num? on 'pilvine taevas'. Sõna tir on ilmses seoses sõnaga tir?? , mis tähendab 'kõige kõrgemat kohta (võrreldes madalama kohaga); pealmist pinda; kinku või küngast'; siia kuulub ka verbaaltüvi tir'lendama'. Sõna algne tähendus võiks olla 'kõrge, ülemine'. Semantiliselt sobib meile hästi neenetsi tir 'pilv < kõrge, ülemine' seos koola-saami sõnaperega *teer-m (Dierbma, dierma, Diermes, dierb- 
ma, või kirjakeele Tiirmes) 'vikerkaar, kõu'. Kui me võtame siia juurde veel karagassi Teere 'jumal, taevas', hantide ja manside Tooremi ja meie Taara, siis võiksime rekonstrueerida algse kuju *tзrs, kus s tähistab määramata lühikest või pikka vokaali, tähendusega 'kõrge, ülemine'. Saami ja obiugri nimedes olev * $m$ oleks sel juhul siis tinglikult teonüümne segment.

Selline rekonstruktsioon on põhjendatav, kuna uurali sõnaalguseline ${ }^{*} t$ on nii samojeedi kui soome-ugri keeltes ikka ${ }^{*} t$. Sellise rekonstruktsiooni vastu on esialgu see, et nganassaani keeles vastab neenetsi sõnale tir 'pilv' sõna ččr $r^{\prime} u$ ? 'pilv'. Me võime oletada, et samojeedi pilve-sõna algkuju algas *čga. Samojeedi keeltes on see afrikaat reeglipäraselt muutunud ${ }^{*} t$-ks, kaotades seejuures oma lõpposa $\breve{s}$. Me võiksime arvata, et nganassaani sõnas on algne afrikaat millegipärast säilinud. Läänemeresoome vaste uurali ${ }^{*} c$-le on aga ${ }^{*} h$, kuna siin kadus kõigepealt afrikaadi esikomponent $t$ ning hiljem toimus reeglipärane muutus $\check{s} \rightarrow h$, saami keeltes peaks sellel kohal olema $c$. Sellisel juhul ei oleks võimalik seada vastavusse eesti Taarat ja saami *teer-mi samojeedi pilve -sõnadega.

Siiski on üsna tõenäone, et nganassaani sõnaalguseline $\check{c}$ on hilisem ebareeglipärane eriareng. Sellele viitavad mitmete nganassaani sõnade paralleelvormid, mis algavad kas $\check{c}$ - või $t$-ga, aga eriti hea tõend eriarengust on nganassaani čúo 'linnutiib', millele vastab neenetsi to 'linnutiib'. Nende sõnade uurali algkuju on *tul$k a$ 'sulg, tiib' (Rédei 1988: I, 535).

Seepärast võime jääda selle juurde, et soome-ugri ja samojeedi sõnad kuuluvad kokku ühtsesse uurali sõnaperre. Põhjasamojeedi keeltes hakkas kõrget või ülemist tähistanud sõna tähistama pilve, lõunasamojeedi keeltes (karagassis) hakkas see sõna tähistama jumalat nii nagu ka obi-ugri keeltes, saami keeles (keeltes) kasutati seda kõue või vikerkaare tähenduses ning läänemeresoome keeltes (eesti) ülijumala nimena. Taara on seega jumal, kes on ise kõrge ning asub kõrgel üleval taevas.

Pita. Uku Masing selle küsimusega ei tegelnud, sest ta võttis antuna Taarapita täheduse 'Taara avita'; selle võimaluse jätsin juba uurimuse alguses kõrvale. Lennart Meri on arvamusega, et Taarapita tähendab 'Taara pikset', tõele üsna lähedale jõudnud. Tüvi pita on tagasiviidav uurali tüvele pi $\delta e$ 'kõrge, pikk', millega on iidsetest aegadest saadik käinud kaasas denominaalne nominaalsufiks -kä (pi $\delta$ - $k \ddot{a}$; Rédei 1988: I, 377-378). Tänapäeva eesti 


\section{Urmas Sutrop}

keeles seostub selle tüvega eelkõige sõna pikk. Sõnakuju pikk on üsna uus, veel hiljuti kasutati sõna pitk, omastav pitka, nagu praegu veel murreteski. Sõna pikk on saadud sõnast pit-ka ( $-k a$ on ülalnimetatud liide) tüvekonsonandi assimilatsiooni teel: pik-k. Samamoodi on sõnast litna assimilatsiooni teel saadud linn : lin-n.

Pikne on samuti moodustatud samast tüvest *pit-ke-ne $>$ pikne. Wiedemanni sõnaraamatus on tänapäeva pikse tähenduses sõnad piken, pikene, piker, pikerlane, piknik ning pitkes ja pitkne. Esimeses rühmas on juba toimunud assimilatsioon $t k: k k$, teises veel mitte, kuid ei esine ühtegi juhtu, kus oleks toimunud vastupidine assimilatsioon $t k: t t$. Seetõttu on aluseta samastada sõna pita piksega. Tundub, et pita on paljas tüvi, mis vastab uurali tüvele pi $\delta$. Enne kui uurime, mis võiks olla selle tähendus, vaatame mõningaid selle tüve tuletisi eesti ja soome keeles. Tüvest ilma * $k$-liiteta on tuletatud partitsiipadjektiiv pidev, soome pitevä 'pikk ja kitsas, peenike'. Eriti huvitavad on soome pitkä 'pikk' võrdlusastmed: keskvõrre pitempi ( pidempi) 'pikem' ja ülivõrre pisin 'pikim'. Nii kesk- kui ka ülivõrre on moodustatud ilma * $k$ elemendita tüvest, ülivõrdes olev näiline - $t$ - kadu on seletatav reeglipärase läänemeresoome häälikumuutusega $t i \rightarrow s i$. See sai meid huvitavas tüves toimuda pärast seda, kui *pite lõpuvokaal oli kõrgenenud $i$-ks: *piti. Neist näidetest on selge, et läänemeresoome tüvi *pite esines ka vabalt ilma $k$-elemendita. Võimalik, et läänemeresoome deskriptiivseks peetav pisi(ke), soome pisku on tüve *pite tuletis variandist *piti > pisi nagu soome pitkä 'pikk' ülivõrdegi pisin puhul. Siin jääb veel lahtiseks lõpuvokaali vaheldus $e \sim a$ : *pite $\sim$ pita. See ei tohiks olla siiski lahendamatu vastuolu, sest paljude $a$-tüveliste adjektiivide keskvõrre on $e$-tüveline. Näiteks must : musta : mustem, pikk : pika : pikem.

Mis võiks olla see *pite tähendus, mis on ka sõnas pita? Mida võiks olla ühist sõnades pikk, pidev ja pisike(ne). Ilmselt mõõt, määr. Ja mis võiks iseloomustada mõõtu? Sugulaskeeltest leiame "pi $i e$ lisatähendusi nagu suur ja suurus. Näiteks kamassi purže 'seisund, kuju; kõrge, suur' ja sölkupi Tazi murde piri 'kõrgus, suurus'. Siin peitubki võti pita tähenduse seletamiseks - pita võib tähendada suurt. Seda tuleb mõista nii abstraktselt kui konkreetselt pikkuse, kõrguse, jõu, vägevuse, väe ja suuruse enda suhtes.

Taarapita nime võiks seega tõlgendada predikatiivselt kui vaeglauset „Taara (on) suur” või ka atributiivselt Taara-suur ehk 
tänapäevasemalt Suur Taara. Või nagu Henriku Liivimaa kroonikas kirjutati "ubi erat mon set silva pulcherrima in qua dicebant indigene MAGNUM DEUM Osiliensium natum, qui THARAPITA vocatur, et de illo loco in Osiliam volasse". ${ }^{22}$

\section{Kokkuvõte}

Taarapita tähendus võib olla Taara (on) suur, Taara-suur ehk Suur Taara. Epiteet pita 'suur' on uurali päritolu. Taara enda päritolu jääb siiski veel lahtiseks. Seda on võimalik pidada laenuks skandinaavia piksejumala nimest Pórr. Samuti on võimalik, et Taara, saami Tiirmes 'pikne' ning handi ja mansi Toorem 'taevas, jumal' on laenatud altai possessiivsest jumalanime kujust teqrim 'mu taevas, mu jumal'. Sellel juhul on siiski võimalik, et eesti Taara ei kuulu sellesse perre ja on ikkagi laen Skandinaaviast. Kolmandaks on võimalik, et Taara kuulub uurali-altai või soome-ugri-altai ühiste sõnade hulka, ning * $m$-element saami ja handi-mansi nimetustes on tinglikult teonüümne. Pallase kirja pandud lõunasamojeedi karagassi Tere, Teere 'taevas, jumal' võib kuuluda eelnevate nimetustega kokku, kuid võib olla ka hiline ja sõltumatu laen altai (tuva) keeltest. Pean küllaltki tõepäraseks kolmandat võimalust, mille järgi Taara on algupärane soome-ugri jumalanimetus, mis on arenenud paralleelselt altai jumalanimetusega teqri.

Neljas ja kõige usutavam võimalus on see, et ka Taara on uurali päritolu ning on moodustatud tüvest ${ }^{*} t 3 r$, mis algselt tähendas kõrget või ülemist. Selle võimaluse puhul võivad kokku kuuluda Taara, koola-saami Tiirmes, handi ja mansi Toorem, lõunasamojeedi (karagassi) Tere, Teere ning põhjasamojeedi neenetsi tir 'pilv < kõrge; lendama' ja nganassaani č́r $r^{\prime} u$ ? 'pilv'. Taara on selle tõlgenduse kohaselt jumal, kes on ise kõrge ning asub kõrgel üleval taevas.

Küllalt tõenäoliselt osutab Aethicuse "Kosmograafias" 8. sajandi keskpaiku kirja pandud Taraconta saar Saaremaad ning tähendab Taarakonda. Samuti võib olla üsna kindel, et Knytlingasaga's nimetatud Turupið (1168 või 1169) on samane Taarapitaga. Henriku Liivimaa kroonika ladinakeelses tekstis esinev nimekuju on Tharapita, mida tuleb lugeda Taarapita. Taarapita tõlgendus Taara (on) suur, Taara-suur ehk Suur Taara - vastab täielikult Henriku Liivimaa kroonika teatele, et Taarapita oli saarlaste suur jumal. 


\section{Urmas Sutrop}

\section{Kirjandus}

Adam von Bremen 1986. Hamburgische Kirchengeschichte: Geschichte der Erzbischöfe von Hamburg. Übersetzt von J. C. M. Laurent \& W. Wattenbach. Alexander Heine (toim). Essen \& Stuttgart: Phaidon.

Adam von Bremen 1987 = M[eister]. Adam's Geschichte der Ausbreitung der christlichen Religion durch die hamburgische und bremische Kirche in dem benachbarten Norden, von Karls des Großen bis zu Heinrichs des IV. Zeiten; wie auch dessen geographische Abhandlung über Dänemark und über die daran gränzenden Länder des Nordens. Aus dem Lateinischen übersetzt und mit erläuternden Anmerkungen begleitet von Carsten Miesegaes. Bremen 1825. Reprintausgabe. Bremen: Carl Schünemann.

Arbusow, Leonid \& Albert Bauer (bearb) 1955. Heinrichs livländische Chronik. 2. Aufl. Monumenta Germaniae Historica, 7, 31. Hannover: Hahn.

Arbusow, Leonid \& Albert Bauer (bearb) 1959. Heinrich von Lettland: Livländische Chronik. Neu übers. v. Albert Bauer Ausgewählte Quellen zur deutschen Geschichte des Mittelalters 24. Darmstadt: Wiss. Buchges.

Ariste, Paul 1981. Keelekontaktid. Eesti keele kontakte teiste keeltega. Eesti NSV Teaduste Akadeemia Emakeele Seltsi toimetised 14. Tallinn: Valgus.

Barandiáran, José Miguel de 1973. Die Baskische Mythologie. Hans Wilhelm Haussig (toim) Götter und Mythen im alten Europa. Wörterbuch der Mythologie, 2. Stuttgart: Ernst Klett, lk 511-552, Tafel I-VIII.

Beck, H. 1986. Donar-Pórr. Johannes Hoops, Reallexikon der Germanischen Altertumskunde. 2. völlig neu bearb. Aufl. Bd. 6. Berlin \& New York: Walter de Gruyter, lk 1-7.

Birkhan, Helmut 1970. Germanen und Kelten bis zum Ausgang der Römerzeit. Der Aussagewert von Wörtern und Sachen für die frühesten keltisch-germanischen Kulturbeziehungen. Österreichische Akademie der Wissenschaften. Philosophisch-historische Klasse: Sitzungsberichte, 272. Wien: Hermann Böhlaus Nachf.

Brückner, A. 1925. Slaven und Litauer. Alfred Bertholet, Edvard Lehmann (toim) Lehrbuch der Religionsgeschichte. 4. vollst. neubearb. Aufl., Bd. 2 Tübingen: Mohr, lk 506-539.

Buck, Carl Darling 1949. A Dictionary of Selected Synonyms in the Principal Indo-European Languages. Chicago: The University of Chicago Press.

Castrén, Mathias Alexander 1853. Vorlesungen über die finnische Mythologie. St. Petersburg.

Clauson, Gerard 1972. An Etymological Dictionary of Pre-ThirteenthCentury Turkish. Oxford: Clarendon Press.

Clemen, Carl 1960. Les Baltes et les Slaves. Histoire Générale des Religions. Tome 1. Paris: Quillet.

Collinder, Björn 1955. Fenno-Ugric Vocabulary. Stockholm: Almqvist \& Wiksell. 
Collinder, Björn 1960. Comparative Grammar of the Uralic Languages. Stockholm: Almqvist \& Wiksell.

Cotterell, Arthur 1986. A Dictionary of World Mythology. New rev. ed. Oxford \& Melbourne: Oxford University Press.

Ehasalu, Epp, Külli Habicht, Valve-Liivi Kingisepp \& Jaak Peebo 1997. Eesti keele vanimad tekstid ja sõnastik. Tartu: Tartu Ülikooli Kirjastus.

Falk, H. S. \& Alf Torp 1960. Norwegisch-Dänisches etymologisches Wörterbuch. 2. Aufl., 2. Teil. Oslo \& Bergen: Universitetsforlaget \& Heidelberg: Carl Winter.

Farkas, Julius von 1954. Die gesellschaftliche Organisation der finnisch-ugrischen Völker im Lichte der Wortkunde. Saeculum. Jahrbuch für Universalgeschichte, Bd. 5, Heft 3, lk 329-335.

Grimm, Jacob 1989. Deutsche Rechtsaltertümer. Nachdr. 4. Aufl., Leipzig 1899. Bd. 2. Darmstadt: Wiss. Buchges.

Grimm, Jacob 1965. Deutsche Mythologie. 3 Bde. (1878). Darmstadt: Wiss. Buchges.

Grimm, Jacob 1880-1888. Teutonic Mythology. 4 Vols. London: W. Swan Sonnenschein and Allen, George Bell and Sons.

Haavio, Martti 1970. Taraphita. Virittäjö, nr 2, lk 120-132.

Handwörterbuch 1929/1930 = Handwörterbuch des deutschen Aberglaubens. Bd. 2. Berlin \& Leipzig: Walter de Gruyter.

Hillkowitz, Kurt 1973. Zur Kosmographie des Aethicus. Teil II. Frankfurt am Main: Vittorio Klostermann (raamatu esimene osa ilmus Kölnis 1934).

Hrkal, Eduard 1947. Der etruskische Gottesdienst. Dargestellt nach den Agramer Mumienbinden. Skizze und Übersetzungen der bis jetzt analysierbaren Inschriften. Wien: Gerold \& Co.

Ishkol-Kerovpian 1986. Mythologie der vorchristlichen Armenien. Hans Wilhelm Haussig (toim), Götter und Mythen der kaukasischen Völker. Wörterbuch der Mythologie; 1, 4. Stuttgart: Klett-Gotha, lk 59-160 \& Tafel I-VI.

Jóhannesson, Alexander 1956. Isländisches etymologisches Wörterbuch. Bern: Francke.

Johansen, Paul 1933. Die Estlandliste des Liber Census Daniae. Mit vollständigem Facsimile. Kopenhagen: H. Hagerup \& Reval: F. Wassermann.

Johansen, Paul 1950. Der altnordische Name Ösels als verfassungsgeschichtliches Problem. Kurt Bussmann \& Nikolaus Grass (toim), Festschrift Karl Haff. Innsbruck: Wagner, lk 95-110.

Jónsson F. (toim) 1954. Ex Historia regum Danorum dicta Knytlingasaga. Monumenta Germaniae Historica. Scriptores 5, 29. Hannover 1892. Nachdruck. Stuttgart: Hiersemann \& New York: Kraus, lk 271-322.

Karjalainen, K. F. 1922. Die Religion der Jugra Völker. Teil II. Folklore Fellows Communications, Vol. 11, Nr 44, Helsinki \& Porvoo, lk 1-386. 


\section{Urmas Sutrop}

Karst, Joseph 1931. Die vorgeschichtlichen Mittelmeervölker nach Ursprung, Schichtung und Verwandschaft. Ethnologisch-linguistische Forschungen. Elsass-Lothringischen Wissenschaftlichen Gesellschaft (Strassburg): Schriften, C, 3. Heidelberg: Carl Winter.

Karsten, T. E. 1936. Zu den ältesten Völker- und Ortsnamen der Ostseeländer. Helmut Arnitz (toim). Germanen und Indogermanen. Festschrift für Herman Hirt. Bd. 2. Heidelberg: Carl Winter, lk 471-492.

Kay, Charles de 1898. Bird Gods. New York: A. S. Barnes.

Kettunen, Lauri 1955. Etymologische Untersuchung über estnische Ortsnamen. Suomalaisen Tiedeakatemian Toimituksia, B, 90, 1. Helsinki.

Kotljarewski, Aleksandr 1871. Eine estnische Gottheit als Gast auf der Insel Rügen. Sitzungsberichte der gelehrten estnischen Gesellschaft zu Dorpat: 1870. Dorpat.

Leach, Marjorie 1992. Guide to the Gods. Toim Michael Owen Jones \& Frances Cattermole-Tally. Santa Barbara, California; Denver, Colorado \& Oxford, England: ABC-Clio.

Leger, L. 1896. Études de Mythologie Slave. Svantovit et les Dieux en «vit». Revue de l'Histoire des Religions. Tome 33, lk 1-18.

Löwe, Heinz 1976. Salzburg als Zentrum literarischen Schaffens im 8. Jahrhundert. Mitteilungen der Gesellschaft für Salzburger Landeskunde, 115. Vereinsjahr 1975. Salzburg, lk 99-143.

Lõugas, Vello 1996. Kaali kraatriväljal Phaetonit otsimas. Tallinn: Eesti Entsüklopeediakirjastus.

Mann, Stuart E. 1984-1987. An Indo-European Comparative Dictionary. Hamburg: Buske.

Masing, Uku 1939. Taara päritolust. Usuteaduslik ajakiri. XI ak., nr 1, lk $1-16$.

Masing, Uku 1995. Eesti usund. Tartu: Ilmamaa.

Meri, Lennart 1976. Hõbevalge. Tallinn: Eesti Raamat.

Meyer-Lybke, W. 1972. Romanisches etymologisches Wörterbuch. 5. Aufl. Heidelberg: Carl Winter.

Moora, H. \& H. Ligi 1970. Wirtschaft und Gesellschaftsordnung der Völker des Baltikums zu Anfang des 13. Jahrhunderts. Tallinn: Eesti Raamat.

Moszyński, Leszek 1992. Die vorchristliche Religion der Slaven im Lichte der slavischen Sprachwissenschaft. Bausteine zur Slavischen Philologie und Kulturgeschichte. Reihe A: Slavistische Forschungen, N. F. 1 [61]. Köln, Weimar \& Wien: Böhlau Verlag.

Munkácsi, Bernát \& Béla Kálmán 1986. Wogulisches Wörterbuch. Budapest: Akadémiai Kiadó.

Must, Gustav 1951. Zur Herkunft des Stadtnamens Reval. FinnischUgrische Forschungen. Bd. 30, Heft 3, lk 303-311.

Mäger, Mart 1967. Eesti linnunimetused. Tallinn: Keele ja Kirjanduse Instituut. 
Mäger, Mart 1994. Linnud rahva keeles ja meeles. 2. tr. Tallinn: Koolibri. Mägiste, Julius 1983. Estnisches etymologisches Wörterbuch. 12 Bde. Helsinki: Finnisch-Ugrische Gesellschaft.

Mägiste, Julius 2000. Estnisches etymologisches Wörterbuch. 2. Aufl. 12 Bde. Helsinki: Finnisch-Ugrische Gesellschaft.

Pallas, Peter Simon 1967. Reise durch verschiedene Provinzen des Russischen Reichs. Nachdruck der Ausgabe St. Petersburg 1771-1776. Bd. 3. Graz: Akademische Druck- u. Verlagsanstalt.

Pallas, Peter Simon 1977. Linguarum totius orbis vocabularia comparativa. Bd. 1. Nachdruck der Ausgabe St. Petersburg 1786. Harald Haarmann (toim). Hamburg: Helmut Buske.

Paulson, Ivar 1962. Die Religionen der nordasiatischen (sibirischen) Völker. Christel Matthias Schröder (toim) Die Religionen Nordeurasiens und der amerikanischen Arktis. Die Religionen der Menschheit, 3. Stuttgart: W. Kohlhammer, lk 1-144.

Pelliot, Paul. 1914. Une communication, I, $2^{\circ}$. Journal Asiatique. Onzième série. Tome 3, No. 2, Mars-Avril. Société asiatique. Séance du 13 Mars 1914, lk 497-500.

Pelliot, Paul 1944. Tängrim > Tärim. T'oung Pao. Vol. 37, Livr. 5, lk 165 185.

Pokorny, Julius 1959. Indogermanisches etymologisches Wörterbuch. 2 Bde. Bern \& München: Francke.

Prinz, Otto (toim) 1993. Die Kosmographie des Aethicus. Monumenta Germaniae Historica: Quellen zur Geistesgeschichte des Mittelalters, 14. München: Monumenta Germaniae Historica.

Puhvel, Jaan 1987. Comparative Mythology. Baltimore \& London: The Johns Hopkins University Press.

Puhvel, Jaan 1996. Võrdlev mütoloogia. Tartu: Ilmamaa.

Raun, Alo 1982. Eesti keele etümoloogiline teatmik. Rooma \& Toronto: Maarjamaa.

Raun, Alo \& Andrus Saareste 1965. Introduction to Estonian Linguistics. Ural-Altaische Bibliothek, 12. Wiesbaden: Otto Harrassowitz.

Rédei, Károly 1988-1991. Uralisches etymologisches Wörterbuch. 3 Bde. Wiesbaden: Otto Harrassowitz.

Rédei, Károly 1996. Über die Herkunft des ungarischen Wortes isten 'Gott'. Linguistica Uralica. Vol. 32. No. 4, lk 283-288.

Reiter, Norbert 1973. Mythologie der alten Slaven. Hans W. Haussig (toim). Göttern und Mythen im alten Europa. Wörterbuch der Mythologie; 1, 2. Stuttgart: Klett, lk 163-208.

Roux, Jean-Paul 1956. Tängri. Essai sur le Ciel-Dieu des peuples altaïques. Revue de l'Histoire des Religions 149, lk 49-82, 197-230 ja 150, lk 2754, 173-212.

Roux, Jean-Paul 1958. Notes additionales à Tängri le Ciel-Dieu des peuples altaïques. Revue de l'Histoire des Religions 154: 32-66. 


\section{Urmas Sutrop}

Roux, Jean-Paul 1987. Tengri. Mircea Eliade (toim). The encyclopedia of Religion. Vol. 14. New York: Macmillan Publishing Company.

Räsänen, Martti 1969. Versuch eines etymologischen Wörterbuchs der Türksprachen. Lexica Societatis Fenno-Ugricae, 17, 1. Helsinki: SuomalaisUgrilainen Seura.

Saagpakk, Paul F. 1982. Eesti-inglise sõnaraamat. Estonian-English dictionary. New Haven \& London: Yale University Press.

Steinitz, Wolfgang 1966. Dialektologisches und etymologisches Wörterbuch der ostjakischen Sprache. Berlin: Akademie-Verlag.

Stokes, Whitely \& Bezzenberger Adalbert, 1979. Wortschatz der keltischen Spracheinheit. 5. unv. Aufl. nach 4. Aufl. 1894. Göttingen: Vanderhoeck \& Ruprecht.

Tarvel, Enn (toim) 1993. Henriku Liivimaa kroonika. Tõlk. Richard Kleis. Tallinn: Olion.

Toporov 1989 = Топоров, В. Н. 1989. Из славянкой языческой терминологии: индоевропейские истоки и тенденции развития. Этимология 19861987. Москва: Наука, lk 3-50.

Trubačev, O. N 1994a. Überlegungen zur vorchristlichen Religion der Slaven im lichte der slavischen Sprachwissenschaft. Zeitschrift für Slavische Philologie 54, lk 1-20.

Trubačev 1994b = Трубачев, О. Н. 1994. Мысли о дохристианской религии славян в свете славянкого языкознания. Вопросы языкознания 43/6, 1k 3-15.

Turner, R. L. 1966. A Comparative dictionary of the Indo-Aryan Languages. London: Oxford University Press.

Vasmer, Max 1958. Russisches etymologisches Wörterbuch. 3 Bde. Heidelberg: Carl Winter.

Vendryes, J. 1981. Lexique Étymologique de l'Irlandais Ancien (Letters T-U par les soins de E. Bachellery \& P.-Y. Lambert, 1978). Dublin: Dublin Institute for Advanced Studies.

Viires, Ants 1990. Taara avita! Looming 10, lk 1410-1421.

de Vries, Jan 1962. Altnordisches etymologisches Wörterbuch. 2. verb. Aufl. Leiden: E. J. Brill.

Waitz, G. (toim) 1964. Ex Saxonis Gestis Danorum. Monumenta Germaniae Historica. Scriptores 5, 29. Hannover 1892. Nachdruck. Stuttgart: Hiersemann \& New York: Kraus, lk 37-161.

Walde-Hofmann 1954 = Walde, A. Lateinisches etymologisches Wörterbuch. 3. neubearb. Aufl. von J. B. Hofmann. Bd. 2. Heidelberg: Carl Winter.

Walde-Pokorny 1930 = Walde, Alois, Vergleichendes Wörterbuch der indogermanischen Sprachen. Julius Pokorny (toim, bearb.) 3 Bde. Berlin \& Leipzig: Walter de Gruyter.

Wieselgren, P. 1947. Namnet Reval. Meijerbergs Arkiv för Svensk Ordforskning. Del. 7, lk 88-116.

Wuttke, Heinrich (toim) 1991. Aethici Istrici Cosmographiam ab Hieronymo ex Graeco in Latinum breviarium redactam. Nachdr. 2. Aufl., Leipzig 1854 (1853). Hildesheim, Zürich \& New York: Georg Olms. 
Urmas Sutrop

\section{Kommentaarid}

${ }^{1}$ Kahjuks ei saa ma toetuda eesti etümoloogilisele kirjandusele. Alo Raun konstanteerib vaid: "taara (usk) vrd. rts. Thor" (1982: 168); sama leiame ka Paul F. Saagpaku eesti-inglise sõnaraamatust: "Taara mütol. chief god of the ancient Estonians ... cf. Scandinavian Thor" (1982: 915). Julius Mägiste etümoloogilises sõnaraamatus on artikkel "III taara,- ,Tara, Verpackung”, millele järgneb "taarausuline s. II taara-” (1983: 3028). Eespool artiklid "I \& II taara" puuduvad. Sõnaraamatu uustrükis (2000) on puuduv lehekülg (3027) küll taastatud, seal leiduv sõnaartikkel "II taara-, Taara, ei selgita aga sõna päritolu.

Pean oma kohuseks tänada kõiki, kes käsikirja lugenud ja arvustanud on. Püüdsin kõiki kriitilisi märkusi ka arvestada. Eriti tänan härra Jaan Kangilaskit toetuse ning abi eest.

${ }^{2}$ Siin ja edaspidi kõik ladinakeelsed tsitaadid Liivimaa kroonikast Arbusowi ja Baueri (1955) järgi ning eestikeelsed vasted Enn Tarveli (1993) toimetatud väljaandest Richard Kleisi tõlkes.

${ }^{3}$ Taarapita on ka traditsiooniline kuju, nii nagu Rävala, Sakala jt muinasnimed

${ }^{4}$ Taarapita nime vanemad käsitlused on kokku võtnud Ants Viires (1990).

${ }^{5}$ Uurijal tasuks vaadata mõlemaid väljaandeid, mitte nende tõlkeerinevuste, vaid kommentaaride pärast. 1826. a väljaande (repr. 1987) kommentaarid on palju põhjalikumad ja skeptilisemad. Uusväljaande kommentaar on võtnud tõe pähe mitmeid Eestit puudutavaid arvamusi, mida varasema väljaande kommenteerija välja naeris.

${ }^{6}$ Õpetatud Eesti Seltsi 375. istungil tegi Kotljarevski (1871: 79) märkuse, et tema antud Tharapita seletus on juba aastast 1853 Schiesneri kaudu tuttav. Ta viitab seejuures joonealusele märkusele töös (Castrén 1853: 329). Ilmselt on see sama raamat, millele viitas Grimm (1965: III, 35) ülaltoodud tsitaadis.

${ }^{7}$ Tõenäoliselt oleks õigem kirjutada eestipäraselt Turupid, mitte aga Turupit.

${ }^{8}$ Siit on ka näha, et skandinaavia nimes Pórr lõpus olev topeltkonsonant (r-r) jaguneb tüvekonsonandiks ja nimetava käände lõpuks.

${ }^{9}$ Metatees tähendab sõnasiseste häälikute ümberpaiknemist.

${ }^{10}$ Gallia jõenimed Taros ja Tara kuuluvad etümoloogiliselt indoeuroopa tüve ter- 'eemale jõudma, läbi tungima' juurde (Walde-Pokorny 1930: II, $732 \mathrm{j}$.

${ }^{11}$ Nii germaani kui keldi piksejumalate nimetused tulenevad heliga seotud tüvedest. Balti piksejumal, leedu Perkunas on veidi teistsuguse tuletusalusega: per-, per-g-, per-q- 'lööma', kuid ka lüües tekib heli (WaldePokorny 1930: II, 42j.). Selle tüve juurde kuulub ka vanaislandi Fjorgyn 'Pórr'i ema'. Ülevaade indoeuroopa piksega seotud sõnavara kohta leidub (Buck 1949: 57j., nr. 1.56 Thunder). Skandinaavia sõja ja õiguse jumal Týr 


\section{Urmas Sutrop}

(siin -r jällegi nimetava käände lõpp) kuulub kokku indoeuroopa taevajumalatega tüvest dyews, deywos; samast tüvest on pärit ka eesti taevas.

${ }_{12}$ Turaani keelte all mõeldakse siin ilmselt nn uurali-altai keeli. Eduard Hrkali arvates kuulub etruski keelgi uurali-altai keelerühma.

${ }^{13}$ Armeenia eelkristliku piksejumala Tork kohta vaata (Ishkol-Kerovpian 1986: 141-143).

${ }^{14}$ Täpita э vastab häälduselt ligikaudu meie õ-le.

${ }^{15}$ Pallase sõnaraamatus on kasutatud küriililist tähestikku. Raamatu alguses lk XVII-XVIII on võti "Explicatio literarum Alphabeti Rossici". Meid huvitavad sõnakujud saab transkribeerida üksüheselt, v.a "§. character in fine verborum adhiberi folitus, pro indicanda fortiore pronuntiatione ultimae consonantis" (säilitan selle märgi) ning “Ы. aequipollet ypsilo graecorum" (seega kirjutan y).

${ }^{16}$ Lihtsustan praegu oma tööd, ning jätan handi ja mansi nimetustest ära diakriitilised märgid. Eestikeelse nimekujuna kasutan kummagi keele puhul Toorem.

${ }^{17}$ Kõik kolm nimetatud sajaanisamojeedi rahvast ja keelt hääbusid tuvastamise tõttu 18. sajandi lõpul. Alamudinski rajoonis Irkutski oblastis tänapäeval elavad karagassid ehk tofalaarid (1970. aastal 620 hinge) on keelelt ja kultuurilt lähedased idapoolsetele tuvalastele. Etniliselt on nad osaliselt sajaanisamojeedi karagasside järeltulijad.

Pallas kirjeldab selles reisikirjas põhjalikult ka hantide uskumusi ja jumalateenistust [Götzendienst] (1967: 59jj) Ta annab jumalanimena hantidel Torom ja Turum ning mansidel Torom. Mordvalaste kohta Volgal annab ta jumalanimeks sulgudes: "(Tschw. Tora)" 'tšuvaši Tora' (1967: 57.)

${ }^{18}$ Soomeugri *šine-re, häälikumuutus š $\rightarrow$ h on läänemeresoome keeltes seaduspärane.

${ }^{19}$ Hiljuti on ka Károly Rédei näidanud, et uurali keeltes (peale ungari ja mordva keele) väljendavad 'taeva' ja 'jumala' mõisteid samad sõnad (1996).

20 "Kosmograafia" tegelik autor ning selle kirjutamise täpne aeg ei ole teada. Varasem traditsioon kasutab nimekuju Aethicus Ister (Istricus), praegune Aethicus.

${ }^{21}$ Mäletatavasti oli Eesti (Aesthland) veel Breemeni Aadamagi arvates saar teiste Läänemere ja Skandinaavia saarte seas.

${ }^{22}$ Lk 175. Kus oli mägi ja väga ilus mets, kus, rääkisid kohalikud, olevat sündinud saarlaste SUUR JUMAL, keda kutsutakse THARAPITAKS, ja sellelt kohalt Saaremaale lennanud; 155b; minu suurelt kirjutatud sõnad - U.S. 